\title{
Assessing the Applicability of Green Building Information Modelling for Existing Green Buildings
}

\author{
Pavithra Rathnasiri $^{1 *}$, Suranga Jayasena ${ }^{2}$, Mohan Siriwardena ${ }^{3}$ \\ ${ }^{1}$ Division of Building Science and Technology, City University of Hong Kong, Kowloon 999077, Hong Kong SAR \\ ${ }^{2}$ Department of Building Economics, University of Moratuwa, Colombo 00100, Sri Lanka \\ ${ }^{3}$ Department of Built Environment, Liverpool John Moores University, Liverpool 0151, UK
}

Corresponding Author Email: stprathnasiri@gmail.com

https://doi.org/10.18280/ijdne.150601

Received: 28 September 2020

Accepted: 10 November 2020

\section{Keywords:}

green building information modeling, existing green buildings, energy simulation

\begin{abstract}
Green Building Information Modelling is a novel approach which address the momentous need of sustainability. It offers more standardized way of creating buildings which in turn optimize the building performances while attending to the sustainable requirements. Comprising numerous techniques, Green BIM ensures more accurate and comprehensive building performances to optimize the energy efficiency of buildings. Thus, there is a considerable advantage to create more energy efficient buildings using Green BIM. However, the use of Green BIM for existing green buildings is very less while new green buildings are managed using Green BIM. Hence, this research focused to assess the applicability of integrating Green Building Information Modelling for existing green buildings through a practical implementation and identifying the potential challenges. Conducting a comprehensive literature survey first, Green BIM techniques and data requirements of Green BIM were reviewed. A single case study was conducted next, to practically apply the Green BIM technology. The data requirements for Green BIM were identified prior to the selection of case for the study. A questionnaire survey was conducted to analyze the data availability including the data identified from literature. Analyzing the survey findings, an existing green building was selected and finally, the steps to be followed for the use of Green BIM were established. The challenges of the implementation were also presented in this study. The findings proved that; Green BIM is a potential technology for the existing green buildings.
\end{abstract}

\section{INTRODUCTION}

Building Information Modeling (BIM) is considered as an advanced technology and systematic process that supports to transform the building designs, constructions and management more innovatively and it is a standardized process that can be used to building analysis [1]. In most of developed countries, BIM has been mandated in building projects due to its growing demand in the construction industry [2]. As defined by Wong and Fan [3], BIM has been developed with various computer software data models which is capable of verifying a building design and simulating building constructions and performances of both new constructions and modernized or renovated buildings. BIM improves the entire construction process while enabling ability of evaluating alternative approaches for decision making [4]. Kymmell [5] has further described that, all stakeholders will be benefited by incorporating BIM for the performance analysis of buildings, as there would be savings of cost and construction time while creating a strong communication and shared network among the stakeholders. Since BIM has been expressively discussed in recent years as a modernized technology resulted from the latest transformations of information technology developments, building owners and facility managers are more concerned in integrating BIM with green buildings and sustainable strategies [3]. Consequently, Motawa and Carter
[6] proved that BIM plays a key role in improving the performance of green buildings. Hence, 'Green BIM' is a popular concept nowadays in building construction industry [7]. Green BIM is considered as the application of BIM to provide data for energy performance evaluation and sustainability assessments [8]. The importance of Green BIM with the evaluation of sustainable and green strategies has been significantly recognized by the construction sector not only because of the ability of making effective decisions but also the ability of building energy modelling and dealing with energy optimizations so that improve the energy efficiency along with sustainable design and construction practices [9]. Moreover, Green BIM is identified as an integrated process based on BIM, green building certification protocol and environmentally sustainable design and practices [10]. As identified by Ilhan and Yaman [11], Green BIM has been discussed as an emerging trend for more sustainable perspectives.

The integration and collaboration of BIM with green concept lead to develop environmentally sound and sustainable buildings while ensuring the elimination of adversative impacts to the environment. Green BIM technology is applicable not only for design and construction but also for the operation and maintenance of existing buildings. Though the green building concept is an escalating trend nowadays, use of Green BIM has been limited only for 
the new green building developments while there is a huge potential to optimize the energy consumption of the existing green buildings using Green BIM [12]. Lin et al. [13] have also mentioned that still there is a possibility to conduct more Green BIM assessments for the energy consumption of buildings. A study conducted on Green BIM in Malaysia, revealed that still there are many complications faced by building owners which can be eliminated by the use of Green BIM [14]. Maskil-Leitan and Reychav [15] have also mentioned that, there is a need of implementing measures for the use Green BIM for effective green building projects. Thus, the key purpose of this research is at investigating the applicability of Green BIM technology to the existing green buildings.

\section{LITERAURE REVIEW}

\subsection{Building information modelling (BIM)}

BIM is a modern approach, applied to create and coordinate the digital information throughout the life cycle of building project including design, construction, operation and maintenance and demolition stages [16]. The many uses of information managed through BIM include decision making, design improvement, cost calculations, document management, performance management and operational management during various stages of building life cycle [17]. Therefore, BIM is considered as a comprehensive database of structural information of a building, making it not only a structural model, but also an IT tool [18]. Because of its ability to rectify errors of early design stages with accurate schedules of constructions, construction sequencing, clash detection and facilitating complex projects, BIM is widely used in construction industry all over the world [19].

Improved real-time coordination between multiple stakeholders through a virtual platform is a massive advantage of BIM, as it can lead to reduced errors due to better coordination. Moreover, BIM enables a data-driven approach for building planning, construction and maintenance [20]. The enhanced communication and collaboration inflicted by BIM lead to changes in the way architects, engineers, surveyors, contractors, building owners, facility managers and suppliers work together [18]. The work of stakeholders in a project are simplified and made efficient as BIM facilitates simultaneously share, amend and access the building's physical and functional information on a building project. In sustainable designs, to ensure people work together throughout a building's life cycle, it is important to engage the end-users and their keen interest in selecting green features [20].

\subsection{BIM for sustainability and green buildings}

BIM consists of attributes which facilitate complex procedure related to sustainable building design, construction and operation such as daylighting and solar access [7]. The performance of sustainability measures can be analyzed effectively using superimposition of multidisciplinary information on a single model using BIM [21]. Due to its ability to facilitate sustainability and building performance analysis, the publications of BIM on sustainable construction has seen an exponential growth [22].

$\mathrm{BIM}$ is considered to have created a digital transformation in built environment towards lean and green concepts [23]. The core of the BIM is made-up of all the software that facilitate $3 \mathrm{D}$ modelling and information management. The main point of this technology is that it makes easier to gather and share data and the collaboration among the stakeholders is enhanced by giving the stakeholders the access to every piece of information through a common data environment (CDE). For green building projects, to support modelling and analysis, four BIM capabilities are often applied including MEP (mechanical, electrical, and plumbing) system modelling, energy and environment analysis, constructability analysis and structural analysis [23].

\subsection{Green BIM}

Green BIM, in practice is identified as the process of using BIM to manage data related to building performance evaluation and sustainability design assessments [24, 25]. The basic components of Green BIM as identified by Hui [8] are shown in Figure 1. Energy analysis through building modelling to identify options to optimize building energy efficiency during the life cycle are included in Green BIM scope. Moreover, Green BIM supports decision making related low carbon investments by facilitating the evaluation of key carbon emission sources [26]. Hence, the prediction of outcomes of construction through a Green BIM based approach allows the professionals to minimize its impact on the environment throughout its life cycle.

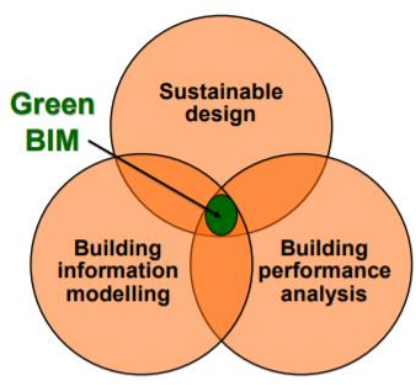

Figure 1. Green BIM components Source: Hui [8]

The energy efficiency of buildings, for example, is one of the elements that characterize sustainability in their life cycle. Maltese et al. [25] confirm that the use of BIM to provide data for energy performance evaluation and sustainability assessment (Green BIM) could enable integrated design, construction and maintenance guiding towards Net Zero Energy buildings. Green BIM includes building energy modelling that deals with energy performance to identify options for energy efficiency during the life cycle.

As pointed out by $\mathrm{Wu}$ and Issa [27], green BIM is the synergies of BIM and green building, which leads to achieve green objectives to improve sustainable outcomes of buildings. Similarly, Liu et al. [21], have stated Green BIM as the use of BIM tools with the aim of achieving improved building performances. Green BIM has integrated with the structure model and simulations which in turn reflects its impact on the environment and supports to improve performance analysis while eliminating potential errors of data handling [6].

\subsubsection{Green BIM triangle taxonomy}

A critical review of BIM for green buildings by Lu et al. [28], considering hundreds of journal articles published from 
1999 to 2016 and 12 widely used types of BIM software, presents a holistic understanding and critical reflection on the relationship between BIM and green buildings, which is systematically illustrated by a "Green BIM Triangle" taxonomy. Figure 2 suggests that the relationship between BIM and green buildings needs to be comprehended based on three dimensions; project phases, green attributes and BIM attributes as described below: (a) Project Phases: BIM in supporting the design, construction, operation, and retrofitting processes of green buildings.

(b) Green Attributes: the various functions of BIM for green building analyses such as energy, emissions, and ventilation analysis.

(c) BIM Attributes: such as BIM in supporting green building assessments.

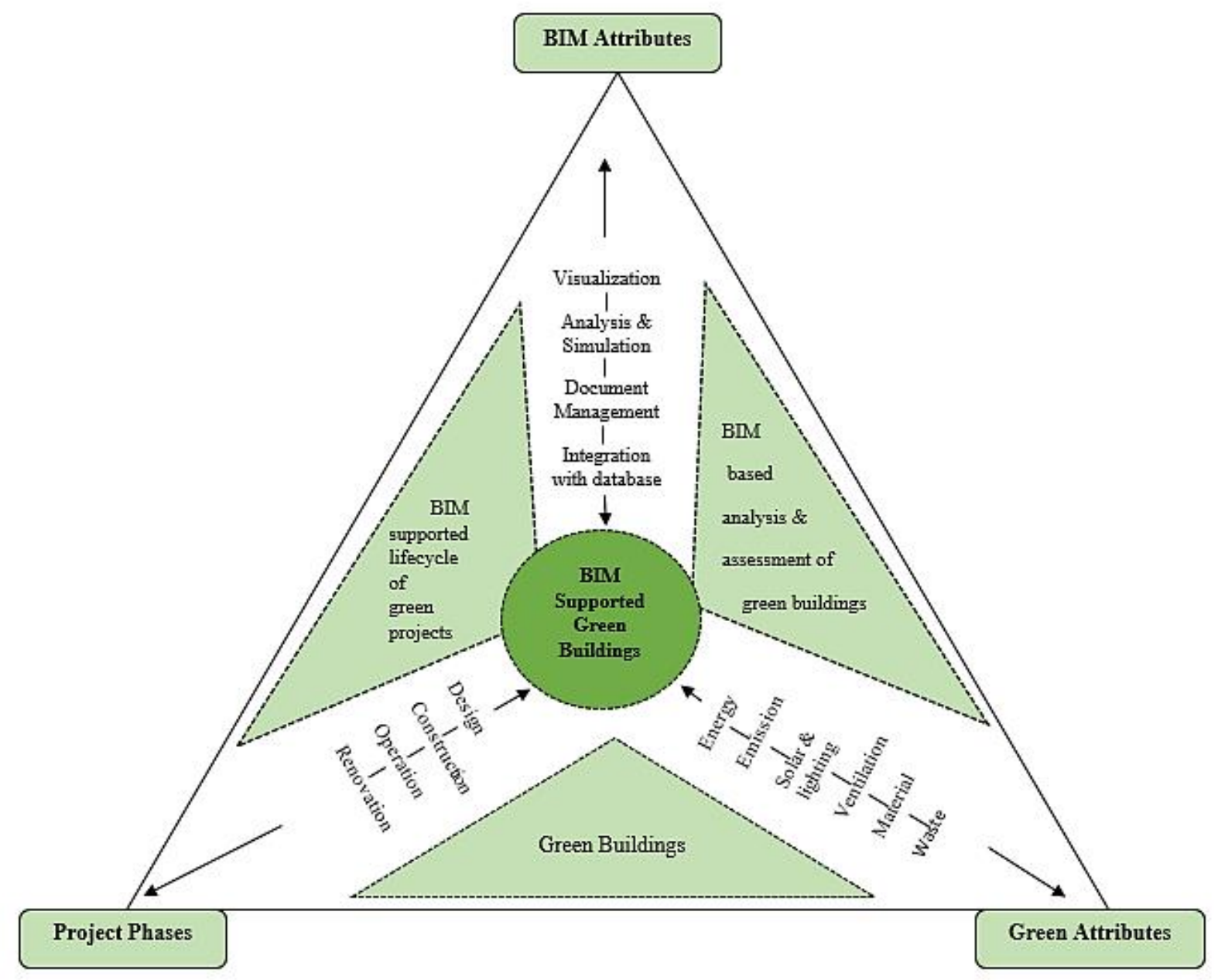

Figure 2. Green BIM taxonomy Source: Lu et al. [28]

Table 1. Green BIM potentials throughout the lifecycle

\begin{tabular}{cc}
\hline Life cycle phase & Green BIM potential \\
\hline Design phase & Facilitate data exchange and integration, provide visualized building performance analysis and simulation, assess \\
design alternatives
\end{tabular}

Potentials of Green BIM throughout the life cycles of green projects is given in Table 1. It can be seen that many of these potentials have not been fully developed and utilized at the present moment, especially in the construction, operation and renovation phases.

It is believed that the main BIM functions for sustainability analyses include energy consumption, carbon emissions, natural ventilation, solar and lighting analysis, acoustics, and water usage. But there is a lack of clear industry standards or codes for the various aspects of Green BIM applications.

\subsubsection{Green BIM models}

BIM platform provides the capability of working in a webbased network while sharing the information and making communication between different project stakeholders [29].

In the traditional process, once the architect completes the basic design, the architectural drawings are received by other project stakeholders and changes and number of refinements are often made making miscommunications and increasing paper works which is a tedious process [6]. Green BIM is a model-based process where each and every project stakeholder 
can be integrated and work simultaneously, in a common platform through the $3 \mathrm{D}$ visualization technology while sharing information stored in BIM database [30]. For example, once the architect develop the basic architectural model of a particular building design, other project stakeholders (MEP engineers, civil engineers, structural engineers) can integrate their models in to the basic BIM model of the building and thereby any mismatches, deformations, structural issues, design issues and any other potential errors can be visualized in $3 \mathrm{D}$ platform so that all project stakeholders can realize at the same time, even they are not occupied a same work space [28]. This process eliminates unnecessary refinements and paper disseminations, improve communications, and optimize building designs so that can avoid the potential errors in the construction of building project in future [31].

From technical point of view, in Green BIM, the basic BIM model of the building is created first and once the model is finalized it is exported to Green BIM simulation software for sustainability analysis [32]. The transformation of model data is done through BIM common file formats which are interoperable. The Green BIM software comprises of various sustainability analysis which supports to enhance the energy efficiency of the building and optimize the sustainability design [33].

\subsubsection{Studies conducted over the application of Green BIM}

A study conducted by of Chong et al. [33] provides a mixed review to determine the current state-of-the-art BIM development for sustainability. The result reveals that although a significant amount of research and development has been done on the use of BIM during various project phases, little work has been conducted on how it could be applied in refurbishment and demolition considering sustianability requirements. Shadram et al. [30] have presented a BIM based framework that supports design decisions and enables assessment of the embodied energy associated with building materials supply chain based on suppliers of Environmental Product Declarations (EPDs).

Ahmad et al. [31] have further developed a conceptual framework of a futuristic BIM-based Design Iteration (BIMDIT) tool for selecting processes, systems, techniques and materials (PSTM) combinations focusing on sustainability achievements. The discussion shows that the PSTM combination selection approach used for the BIM-DIT tool will help decision makers with precise knowledge of available options for achieving truly sustainable building projects.

According to the further recent scholarly research, the ability of BIM to assist in achieving green building certification has also been demonstrated. For example, Biswas et al. [34], have developed a tool incorporating BIM technology to the rating and certification of green buildings to evaluate the environmental consequences of design decisions. Barnes and Castro-Lacouture [35], have suggested that 13 credits and 1 prerequisite in the LEED rating system can be directly acquired by using the Autodesk Revit. Azhar et al. [36] have also found that 17 credits and 2 prerequisites (which result in 38 points in the LEED) can be assessed by adopting BIM software of Autodesk Revit or IES Virtual Environment. Similarly, Gandhi and Jupp [37] have examined the potential application of BIM for the Australian Green Star Building certification. Wong and Kuan [32] have also explored the potential for the application of BIM in facilitating the BEAM Plus green certification in Hong Kong. According to this study, 26 credits in this certification can be awarded out of 80 points through the documentation produced by Autodesk Revit BIM software.

Moreover, Azhar et al. [36] have presented a conceptual framework which establish the relationship between BIMbased sustainability analyses and LEED certification process. $\mathrm{Wu}$ and Issa [27] have also proposed a 3rd-party web service based on BIM as the information backbone in facilitating the LEED documentation. Besides, Ilhan and Yaman [11] have examined the feasibility of 3D simulation transfer processes to recognize the environmental assessment of buildings that have been designed digitally using BIM with a case study, for LEED evaluation.

\subsection{Benefits of Green BIM}

Green BIM has provided numerous benefits during the project life cycle compared to the traditional practices. Traditional practices are required human intervention and interpretation, which leads the analysis too costly and time consuming. According to, Azhar and Brown [38], BIM with sustainability tools have overcome the said difficulties since it has an integrated database of coordinated information. As BIM represents a building in 3D model, its enhanced visualization helps designers and owners to perceive how the technologies have been fitted within the facility [13]. Furthermore, following benefits have been identified on Green BIM.

1. An integrated Green BIM system facilitates the proper collaboration and communication between project teams to effectively provide a well-performing building during operations [39].

2. Facilitates complicated and sophisticated procedures of sustainable designs including day lighting analysis and solar shading analysis, energy analysis, resource management, acoustic analysis and cost analysis [36].

3. Evaluations of building performances and selection of optimum approaches that minimize the unnecessary utilizations of resources including energy, water and materials [24].

4. Improves the safety by anticipating problems and provides a better living environment and helps to reduce principal and operational costs through improved utilization of materials and energy efficiency [7].

5. For the existing buildings, building performances could be evaluated in order to identify the cost savings of the building [6].

\subsection{Green BIM techniques}

Azhar et al. [36], have mentioned that, BIM can ensure better integration with building performance analyses for an optimized sustainable design and BIM based sustainability analyses, which has a significant impact over time and cost savings than the traditional methods. BIM software are primarily used to design the basic BIM models and export into BIM simulations software for sustainability based analyses [32]. The major Green BIM techniques used include energy and thermal analysis, lighting analysis, shadows and shadings analysis, acoustic analysis and lifecycle cost analysis [6]. The information created in the BIM model is usable to conduct such analysis, simulate performance and visualize appearance. Further, Zanni et al. [40] has indicated the aspects, where BIM can support in achieving sustainable designs as effects of building orientations, day lighting and solar cumulating 
analysis, water harvesting, energy performances, performance of sustainable materials, effects on building site and logistics management.

\subsection{Inherent green techniques in BIM}

BIM software such as Revit have been included several green strategies as building orientation and appropriate degree of massing. Effects on building orientations for sustainable design is identified by optimum positioning of the building on site, in relation to the path of sunlight since it has a big impact on energy efficiency and comfort of occupants. BIM has already contained data which are needed to find the solar south. This would be essential to identify the heat gain and day lighting aspects inside the building and for optimal design of heating and cooling plants which lead to minimize the energy cost [41]. Basic techniques which have been included in Green BIM could be summarized as shown in Figure 3.

\subsection{Application of Green BIM}

Green BIM can be used in design, construction and operation and maintenance stages of any building project. When BIM has been used during the design stage of the project, the operation and maintenance stage can also be maintained using developed BIM model and it is easier to apply Green BIM to achieve desired sustainable outcomes [1]. In cases where BIM has not been used in early stages, as built BIM model should be created first, for the existing buildings for the application of Green BIM. For the use of Green BIM later for buildings which have not been constructed using BIM in early stages and are under operation and maintenance phase, availability of building design and construction data however is significant [11].

In the prevailing literature, BIM has been widely used in design stage and therefore, application of Green BIM for existing buildings is considerably less despite the significance and potential of optimizing energy in buildings which are in existing conditions. Hence, the focus of this study is based on the application of Green BIM for existing buildings which have not been constructed using BIM and are under operation and maintenance phase [13].

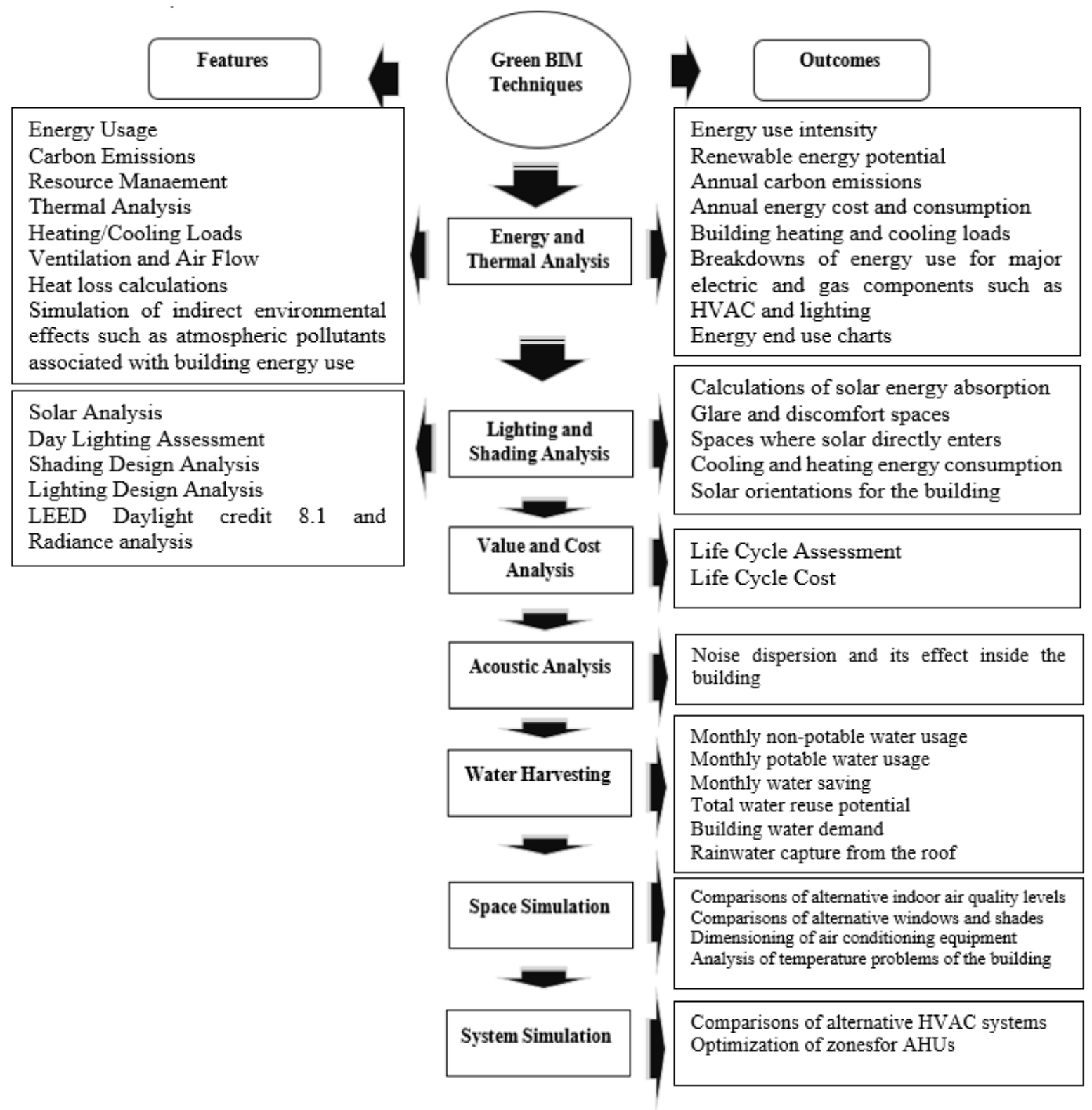

Figure 3. Green BIM techniques 


\subsection{Data required for Green BIM}

Input data which are primarily required for the building simulation tools / BIM based sustainability analyses tools have been mentioned as building geometry data and simulation data. The geometry data of the entire building envelope including all the building components are used for simulations which could be represented as objects [42]. Also, the simulation data are equally important and required for the Green BIM simulations [43], as shown in Figure 4.

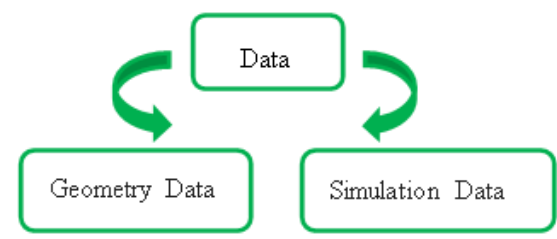

Figure 4. Basic input data requirements

Table 2. Input data requirements

\begin{tabular}{|c|c|}
\hline Geometry Data & Simulation Data \\
\hline $\begin{array}{c}\text { Details of building floor } \\
\text { plans }\end{array}$ & Number of occupants \\
\hline $\begin{array}{l}\text { Details of doors and } \\
\text { windows }\end{array}$ & $\begin{array}{c}\text { Number of days of occupancy per } \\
\text { month }\end{array}$ \\
\hline Building specifications & $\begin{array}{c}\text { Number of hours of a working } \\
\text { day }\end{array}$ \\
\hline $\begin{array}{l}\text { Details of building } \\
\text { elevations }\end{array}$ & $\begin{array}{l}\text { HVAC system types, efficiencies } \\
\text { and operating schedules } \\
\text { Hot water system types. }\end{array}$ \\
\hline Details of building roofs & $\begin{array}{c}\text { efficiencies and operating } \\
\text { schedules }\end{array}$ \\
\hline $\begin{array}{c}\text { Sectional details and } \\
\text { drawings }\end{array}$ & $\begin{array}{l}\text { Lighting types, efficiencies and } \\
\text { operating schedules }\end{array}$ \\
\hline Foundation information & Utility rates, Sound sources \\
\hline $\begin{array}{l}\text { Details and dimensions of } \\
\text { beams and columns }\end{array}$ & $\begin{array}{c}\text { Types of fixtures, Types of } \\
\text { equipment } \\
\text { Fixture count, Number of } \\
\text { equipment } \\
\text { Indoor temperatures, Number of } \\
\text { occupants } \\
\text { Types of materials } \\
\text { Volume of materials } \\
\text { Cost of capital of the building } \\
\text { Costs of operation \& maintenance } \\
\text { \& NPV indicators }\end{array}$ \\
\hline
\end{tabular}

Adopted from: (Sources: Wong and Fan [3], Solla et al. [7], Wu and Issa [27], Azhar et al. [36], Wang et al. [42], Kim et al. [43], Bu et al. [44])

Bu et al. [44] have stated, the initial input data requirements which should be included for the simulation software including the type of building, building systems such as HVAC systems, building materials used, geographical location of the building with weather files and types of zones. Besides, physical and thermal properties of buildings, building internal heat gains and cooling loads, building schedules and operational strategies, HVAC data and simulation correlated parameters should be included to the simulation tools [42]. Input data such as material types and properties could be added to the simulation tools and applied where the additional information required depending on the user's needs. Such additional information would be mentioned including duration of the simulation, site location, utility rates, report types and layer constructions [43].

As identified by Azhar et al. [36], location data would be included with city and state, latitude, longitude, altitude, ground reflectance rating, topography and wind exposure rating. For an instance, where the BIM model is not created for the design of the building, a new BIM model should be created first for the integrated sustainability analysis for existing buildings. In such instances, the primary data of building design would be needed to create the BIM model, before analyses and this would be highly relied on the availability of required drawings and design specifications of the existing building. As examples of few geometry data can mention the dimensions of walls, floors, roofs, ceilings, doors and windows and other specifications. Importantly, the input data requirements are depended upon the specific type of simulation and the corresponding green BIM software which comprises each analysis. Table 2 shows the summary of input data requirements.

\section{RESEARCH METHODOLOGY}

A comprehensive literature review was conducted first to identify the data required for the Green BIM. Subsequently, a questionnaire was developed including the data gathered from the literature. The questions formed in the questionnaire was to mention the available data and non-available data from the given data list which are identified from literature. Questionnaire survey was conducted focusing the existing green buildings which have been accredited LEED rating system. The sample for the questionnaire survey was selected using convenience sampling method. Mainly, out of 40 respondents, 33 answered questionnaires were received. The survey was conducted on existing green buildings certified under the categories of LEED certification including new construction and renovation, building core and shell development, design of commercial interiors and operation and maintenance of existing buildings. The findings of the questionnaire survey revealed the available and non-available data in each green building. Accordingly, the level of data availability was established with percentages for each case separately.

Finally, a single case study was conducted by practically implementing Green BIM energy simulation for a selected green building. Accordingly, the case with showed highest data availability was used for the case study, among the surveyed green buildings. The highest data availability was selected as it presents the maximum number of available data and facilitates the implementation of Green BIM. The reason to analyse the data availability was, as the use of Green BIM is mainly depended on the availability of required Green BIM data. In the case study, two main steps were included as model creation and simulation. The model creation was carried out using the Autodesk Revit 2017 BIM designing software and simulation was done using web-based Autodesk Green Building Studio software. Only the energy simulation was performed for the selected case using the software. During the case study, the challenges were identified which were aroused within the practical context and further challenges and solutions were discussed in order to analyse the applicability of Green BIM for the existing green buildings.

\section{FINDINGS AND ANALYSIS}

\subsection{Analysis of the data availability}

Based on the feedback of questionnaires, data availability 
of each respondent was analysed and calculated using Microsoft excel. Input data were analysed under each data category, rating system and building category. Available data were separately marked under each respondent to identify the total data availability with the percentages.

The available data and non-available data were clearly demonstrated in the analysis in order to recognize the higher data maintainability, as shown in Table 3. This table shows the overall data availability of all respondents in every building category which are coming under each green rating system. Accordingly, the percentage value of each available data in every building category is separately presented under each rating systems, while the rating system of operation and maintenance of existing buildings, separately presents the data availability under each respondent, since it includes the respondent (R26) which had the highest data availability.

According to the above analysis and results, it is obvious that, the required Green BIM data are available for an acceptable level (more than 50\%). Thus, as the next step, a flowchart diagram which is shown in Figure 5, was developed including the steps to be followed to practically use the Green BIM. This was developed so that the data availability can be further analyzed in the practical context.

Table 3. Analysis of data availability

\begin{tabular}{|c|c|c|c|c|c|c|c|c|c|c|c|}
\hline \multirow[t]{3}{*}{ Name of Data } & \multirow{3}{*}{$\begin{array}{c}\text { New } \\
\text { Construction \& } \\
\text { Renovation } \\
(\mathbf{1 0 0 \%})\end{array}$} & \multirow[t]{3}{*}{$\begin{array}{l}\text { Building Core } \\
\text { \& Shell } \\
\text { Development }\end{array}$} & \multirow[t]{3}{*}{$\begin{array}{l}\text { Design of } \\
\text { Commercial } \\
\text { Interiors }\end{array}$} & \multirow{2}{*}{\multicolumn{7}{|c|}{$\begin{array}{c}\text { Operation \& Maintenance of Existing } \\
\text { Buildings }\end{array}$}} & \multirow[t]{3}{*}{$\begin{array}{c}\text { Total } \\
\text { (B) }\end{array}$} \\
\hline & & & & & & & & & & & \\
\hline & & & & R24 & $\mathbf{R 2 5}$ & R26 & R27 & R28 & R29 & R30 & \\
\hline \multicolumn{12}{|c|}{ Building geometry data } \\
\hline Floor Plan & 100 & 100 & 100 & $\sqrt{ }$ & $\sqrt{ }$ & $\sqrt{ }$ & $\sqrt{ }$ & $\sqrt{ }$ & $\sqrt{ }$ & $\sqrt{ }$ & 100 \\
\hline Doors, Windows & 65.21 & 100 & 100 & $\sqrt{ }$ & & $\sqrt{ }$ & $\sqrt{ }$ & & $\sqrt{ }$ & $\sqrt{ }$ & 67 \\
\hline Specifications & 21.73 & 100 & 100 & & & $\sqrt{ }$ & & & & $\sqrt{ }$ & 24 \\
\hline Elevation & 95.65 & 50 & & & $\sqrt{ }$ & $\sqrt{ }$ & $\sqrt{ }$ & $\sqrt{ }$ & $\sqrt{ }$ & $\sqrt{ }$ & 89 \\
\hline Roof Plan & 95.65 & 50 & 100 & $\sqrt{ }$ & $\sqrt{ }$ & $\sqrt{ }$ & $\sqrt{ }$ & & $\sqrt{ }$ & $\sqrt{ }$ & 91 \\
\hline Sections & 78.26 & 100 & 100 & & & $\sqrt{ }$ & $\sqrt{ }$ & $\sqrt{ }$ & & & 72 \\
\hline Foundation & 39.13 & 50 & & & & $\sqrt{ }$ & & $\sqrt{ }$ & & & 66 \\
\hline $\begin{array}{l}\text { Beams and } \\
\text { Columns }\end{array}$ & 78.26 & 50 & & & & $\sqrt{ }$ & $\sqrt{ }$ & $\sqrt{ }$ & & & 66 \\
\hline \multicolumn{12}{|c|}{ Simulation Data } \\
\hline $\begin{array}{l}\text { Number of } \\
\text { occupants }\end{array}$ & 100 & 100 & 100 & $\sqrt{ }$ & $\sqrt{ }$ & $\sqrt{ }$ & $\sqrt{ }$ & $\sqrt{ }$ & $\sqrt{ }$ & $\sqrt{ }$ & 100 \\
\hline $\begin{array}{l}\text { Number of days of } \\
\text { occupancy per } \\
\text { month }\end{array}$ & 100 & 100 & 100 & $\sqrt{ }$ & $\sqrt{ }$ & $\sqrt{ }$ & $\sqrt{ }$ & $\sqrt{ }$ & $\sqrt{ }$ & $\sqrt{ }$ & 100 \\
\hline $\begin{array}{l}\text { Number of hours of } \\
\text { a working day }\end{array}$ & 100 & 100 & 100 & $\sqrt{ }$ & $\sqrt{ }$ & $\sqrt{ }$ & $\sqrt{ }$ & $\sqrt{ }$ & $\sqrt{ }$ & $\sqrt{ }$ & 100 \\
\hline $\begin{array}{l}\text { HVAC system } \\
\text { types, efficiencies } \\
\text { and operating } \\
\text { schedules }\end{array}$ & 91.33 & 50 & & $\sqrt{ }$ & & $\sqrt{ }$ & $\sqrt{ }$ & $\sqrt{ }$ & & $\sqrt{ }$ & 81 \\
\hline $\begin{array}{l}\text { Hot water system } \\
\text { types, efficiencies } \\
\text { \& operating } \\
\text { schedules }\end{array}$ & 34.78 & & & & & $\sqrt{ }$ & $\sqrt{ }$ & & & & 30 \\
\hline $\begin{array}{c}\text { Lighting types, } \\
\text { efficiencies \& } \\
\text { operating schedules }\end{array}$ & 100 & 100 & 100 & $\sqrt{ }$ & & $\sqrt{ }$ & $\sqrt{ }$ & $\sqrt{ }$ & $\sqrt{ }$ & $\sqrt{ }$ & 93 \\
\hline Utility rates & 100 & 100 & 100 & $\sqrt{ }$ & $\sqrt{ }$ & $\sqrt{ }$ & $\sqrt{ }$ & $\sqrt{ }$ & $\sqrt{ }$ & $\sqrt{ }$ & 100 \\
\hline Types of fixtures & 52.17 & 50 & & & & & & & & & 36 \\
\hline Fixture count & 95.65 & 100 & 100 & & & $\sqrt{ }$ & $\sqrt{ }$ & & $\sqrt{ }$ & $\sqrt{ }$ & 84 \\
\hline Indoor temperatures & 100 & 100 & 100 & $\sqrt{ }$ & $\sqrt{ }$ & $\sqrt{ }$ & $\sqrt{ }$ & $\sqrt{ }$ & $\sqrt{ }$ & $\sqrt{ }$ & 100 \\
\hline Types of materials & 69.56 & 50 & 100 & & & $\sqrt{ }$ & $\sqrt{ }$ & & $\sqrt{ }$ & $\sqrt{ }$ & 66 \\
\hline Volume of materials & 26.08 & & & & & & $\sqrt{ }$ & & & & 21 \\
\hline $\begin{array}{l}\text { Cost of capital of } \\
\text { the building }\end{array}$ & 100 & & & & & $\sqrt{ }$ & & & & & 72 \\
\hline $\begin{array}{l}\text { Costs of operation } \\
\& \text { maintenance }\end{array}$ & 100 & 100 & 100 & $\sqrt{ }$ & $\sqrt{ }$ & $\sqrt{ }$ & $\sqrt{ }$ & $\sqrt{ }$ & $\sqrt{ }$ & $\sqrt{ }$ & 100 \\
\hline $\begin{array}{l}\text { NPV indicators for } \\
\text { whole life cycle of } \\
\text { the assets }\end{array}$ & 100 & 100 & 100 & $\sqrt{ }$ & $\sqrt{ }$ & $\sqrt{ }$ & $\sqrt{ }$ & $\sqrt{ }$ & $\sqrt{ }$ & $\sqrt{ }$ & 100 \\
\hline Sound sources & 91.3 & 50 & 100 & $\sqrt{ }$ & $\sqrt{ }$ & $\sqrt{ }$ & $\sqrt{ }$ & $\sqrt{ }$ & $\sqrt{ }$ & $\sqrt{ }$ & 90 \\
\hline Types of equipment & 52.17 & & & & & $\sqrt{ }$ & & & $\sqrt{ }$ & $\sqrt{ }$ & 45 \\
\hline $\begin{array}{l}\text { Number of } \\
\text { equipment }\end{array}$ & 100 & 100 & 100 & $\sqrt{ }$ & $\sqrt{ }$ & $\sqrt{ }$ & $\sqrt{ }$ & $\sqrt{ }$ & $\sqrt{ }$ & $\sqrt{ }$ & 100 \\
\hline $\begin{array}{l}\text { Total availability of } \\
\text { the data (A) }\end{array}$ & 88.52 & 63 & 65 & 53 & 50 & 92 & 80 & 61 & 65 & 73 & \\
\hline
\end{tabular}




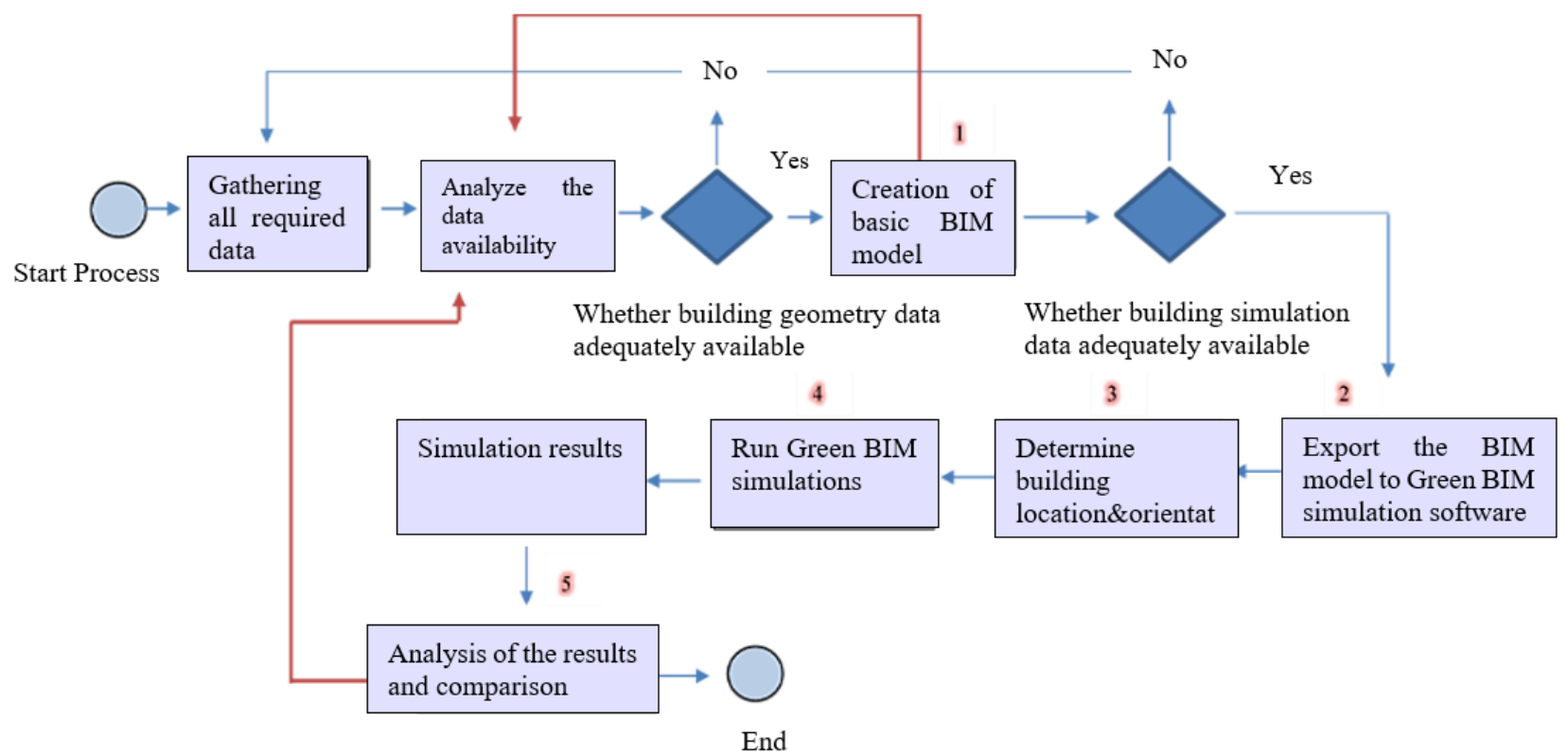

Figure 5. Basic flow of process for the practical implementation of Green BIM

The reason for that was the accuracy of data is also a significant factor to implement Green BIM in existing green buildings since buildings have been constructed years ago. This was applied to use Green BIM for the case study green building which was resulted with highest data availability in the survey.

As shown in Figure 5, the required data are gathered first and secondly, the data availability is analyzed through the creation of building model in BIM and running Green BIM techniques using the model. The availability of building geometry data is analyzed by the process of creating the basic BIM model of the building. The availability of building simulation data is also analyzed while conducting simulations by exporting the BIM model to a Green BIM simulation software and comparing the analysis results with actual results of the building. The comparison was limited to few of available actual results, since all the analysis results coming from the software, were not available. Such comparison was focused to analyze the availability of simulation data up to a certain level, for further clarification of data availability. Within these two processes, any deviations of available data would be recognized. These two steps are reconnected to the start as shown by red highlighted arrows. For simulations, the location and orientation of the building should be specified using the geometry map given in the simulation software, after exporting the BIM model and before running the simulations. It is important to ensure that the directions of solar path over the building is corrected and weather data are properly specified, which directly affect to the simulation results such as energy analysis and day lighting analysis.

\subsection{Application of Green BIM techniques in the case study}

Accordingly, the case study was carried out following the steps formed in Figure 5, focusing on identifying the potential of Green BIM technology. Case study was done for respondent 26 which had the highest percentage for overall data availability. R26 was resulted in $92 \%$ of data availability and it was certified for LEED platinum under the rating system of operation and maintenance of existing buildings. In the case study, the selected green building was first subjected to the creation of its building model in BIM using Autodesk Revit software and subsequently, the energy analysis was conducted for the created building model, using Autodesk Green Building Studio, which is a popular BIM based energy simulation software. The steps followed for the case study are discussed in this section.

\subsubsection{Step 01 - creation of the building model in BIM}

Using Autodesk Revit BIM software, the BIM model of the selected case was created first as shown in the Figure 6. Figure 6 shows the image of actual building and its created BIM model. During the model creation, it was first identified that there was a difference between CAD drawing and the paper drawing of the building. There were considerable changes in the building model elements which are difficult to correct and thus the model was uncompleted. This was basically occurred due to the error dimensions of the AutoCAD drawing which included error roof dimensions, error wall dimensions and spaces. Thus, it was clear that, though data were readily available, accuracy and the reliability are uncertain in this data. Hence, depending on mere the availability of data, accuracy cannot be proved and thus the potential to use Green BIM is also uncertain. Hence, identifying the errors, model was recreated according to the as- built paper drawing.

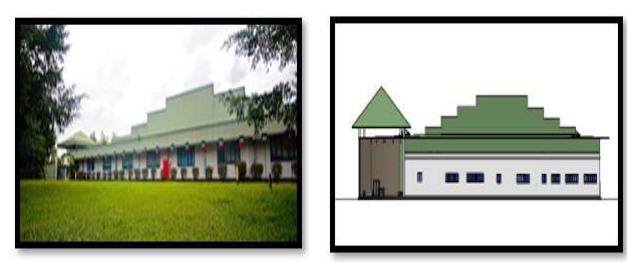

Figure 6. Actual building and created BIM model

\subsubsection{Step 02 - exporting model to the simulation software}

Once the BIM model creation is finished, it was exported by the BIM design software (Revit) to the Autodesk Green Building Studio, which is a Green BIM simulation software. The model was exported through the gbxml data transferring format as the interoperability standard between Revit and GBS, as shown in Figure 7. 


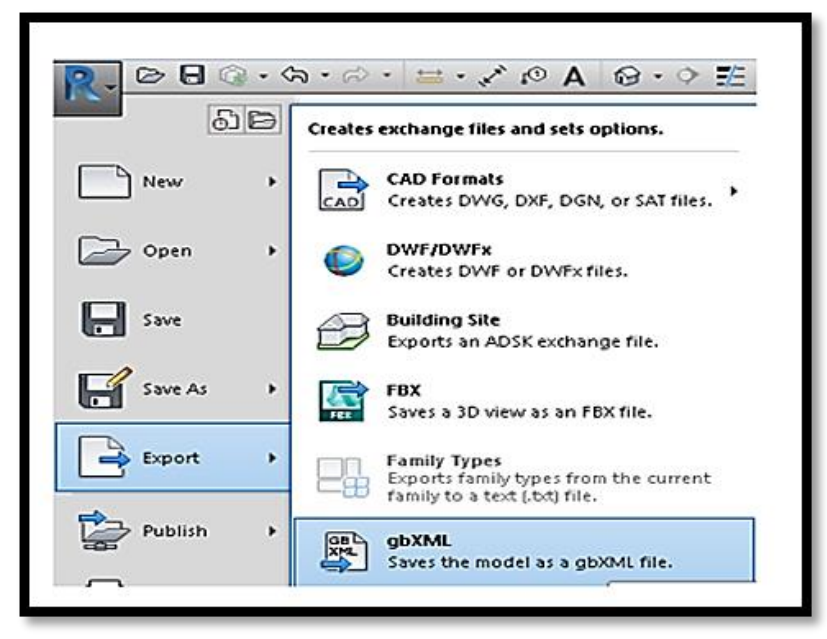

Figure 7. Exporting model via gbxml

After exporting the model to the simulation software, basic parameters were specified including building type, location, project phase, building envelope, ground plane and export category which are important parameters for simulation.

\subsubsection{Step 03 - Determination of the geographical location}

As the third step, location data were included to the software for the energy simulations. In this step, different types of contextual information were included to simulate the energy analysis, such as geographic location, site location and related information including weather data for a typical year. Once the location data included, information of the building location such as the values of latitude and longitude, altitude, details of city and state with the time zone were obtained. Figure 8 shows the interface of the selection pane of geographical information. As highlighted in the Figure, under "project location" address of the building location should be given.

It was important to set the details of building location to define the relevant climatic and weather conditions which make an impact to the overall building energy performance. Once the building location is selected, required simulation data should be entered to the GBS software which were identified previously. Simulation data included the type of HVAC system and their efficiencies, building occupancy, lighting details and efficiencies, indoor and outdoor temperatures.

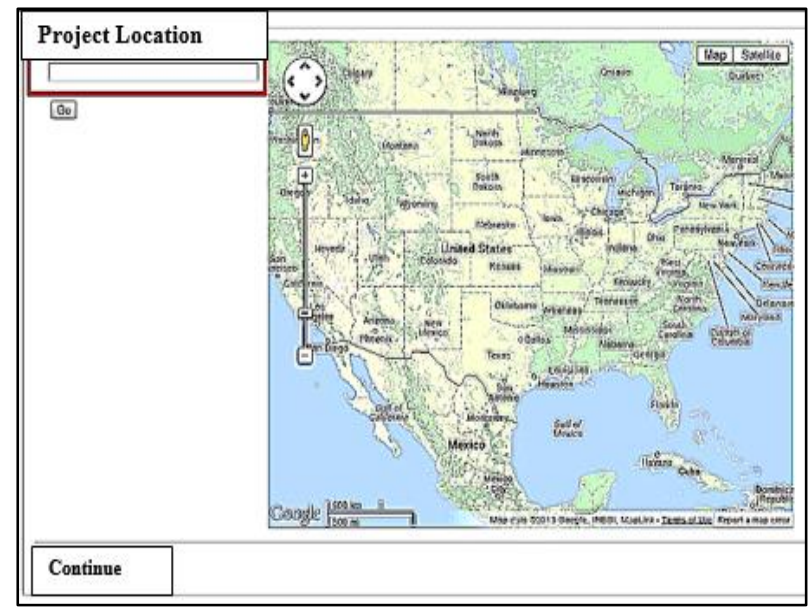

Figure 8. Setting geographic location

\subsubsection{Step 04 - running energy simulations}

Once the required simulation data were entered, the gbxml file of the building model, which transfer the building data to GBS was uploaded to the GBS software to run the energy simulations. The resulted energy simulation information is presented in this section. Table 4 shows the results of energy, carbon and cost simulations.

Table 4. Energy simulation results

\begin{tabular}{ll}
\hline \multicolumn{2}{l}{ Energy, Carbon and Cost Simulation Summary } \\
\hline Annual Energy Cost & $\mathrm{RS} .18,900,000$ \\
Life Cycle Cost & $\mathrm{RS} .121,172,875.320$ \\
Annual CO $\mathrm{CO}_{2}$ Emissions & \\
Electric & $21.7 \mathrm{Mg}$ \\
Onsite Fuel & $85.2 \mathrm{Mg}$ \\
Annual Energy & \\
Energy Use Intensity (EUI) & $532.35 \mathrm{MJ} / \mathrm{m}^{2} / \mathrm{Year}$ \\
Electric & $2,542,324.00 \mathrm{kWh}$ \\
Fuel & $359,124 \mathrm{MJ} / \mathrm{kg}$ \\
Annual Peak Demand & $10,800.00 \mathrm{KVA}$ \\
\hline
\end{tabular}

Following energy consumption charts were further resulted from GBS relating to the building energy performance.

Figure 9 shows the energy end use charts resulted from simulations. It includes the annual electric usage and fuel usage.

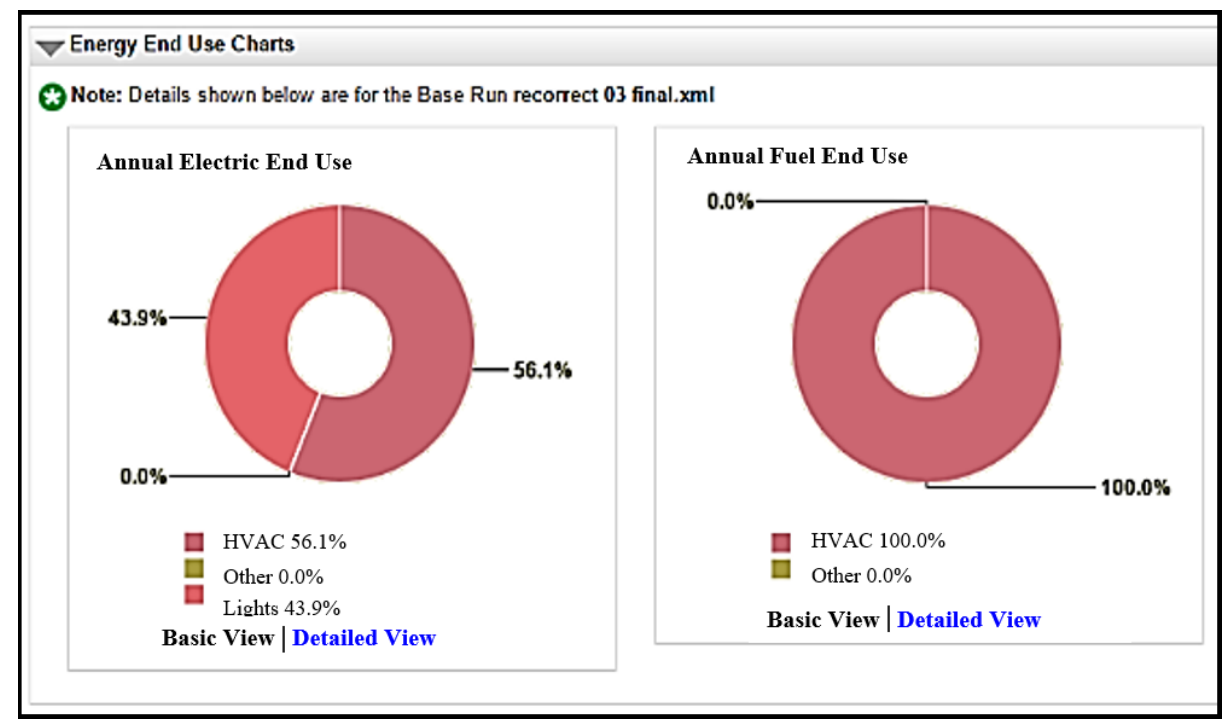

Figure 9. Energy consumption charts 


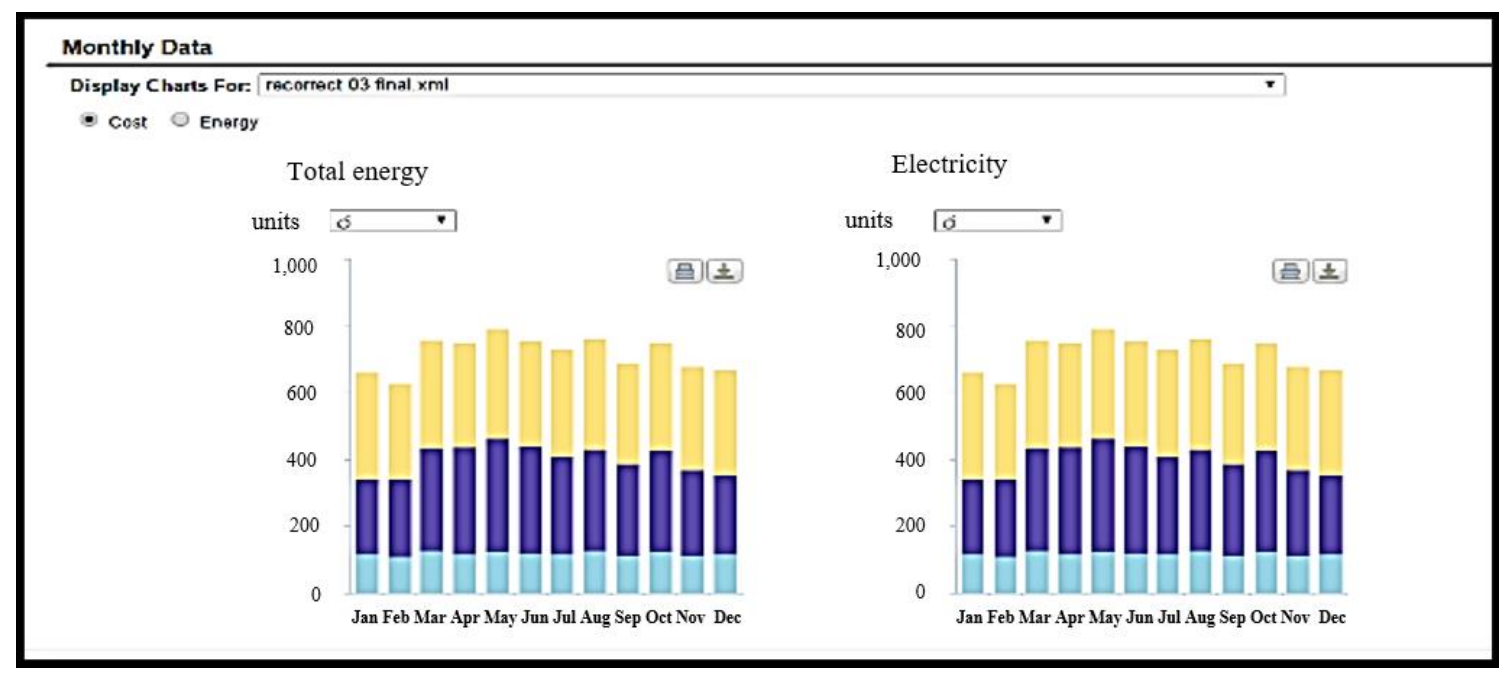

Figure 10. Monthly cost data

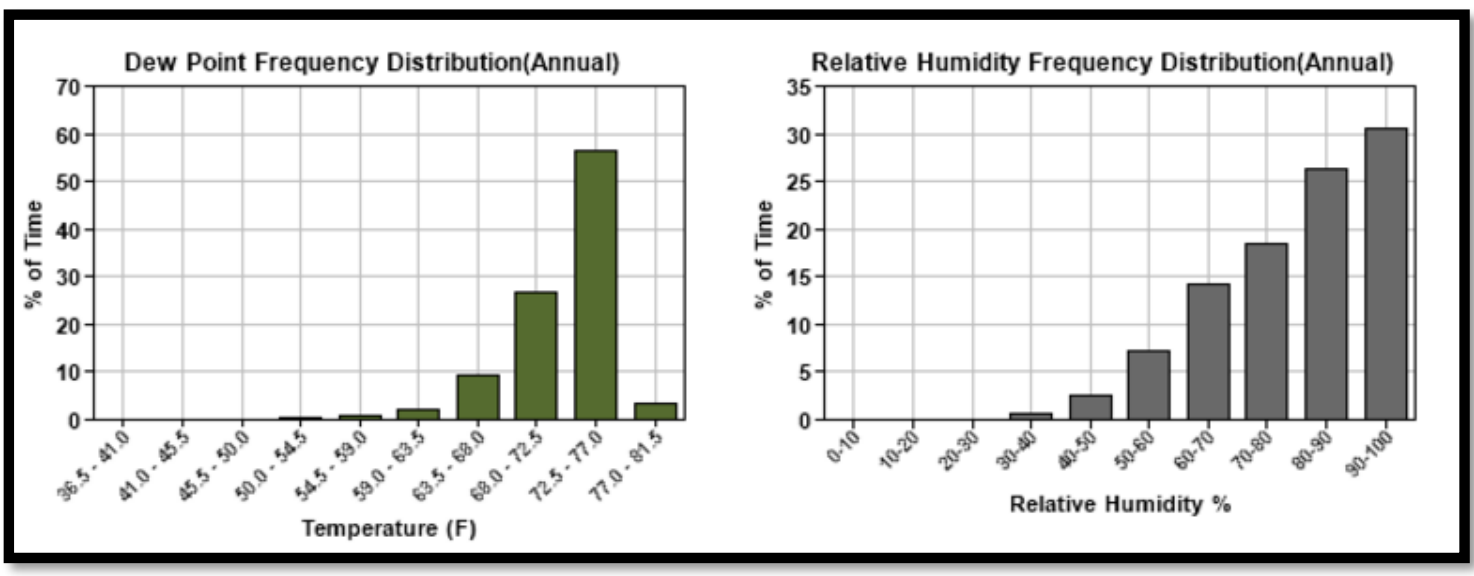

Figure 11. Dew point and relative humidity frequency distribution

Energy simulation results were further included monthly cost data of the building separately for area lights which shows by (yellow), space cooling (dark blue) and vent fans (light blue), as shown in Figure 10.

The Figure 11 presents the dew point frequency and relative humidity frequency distribution for a year. These simulation results are important to control the conditioned air distribution to the building properly by monitoring the dew point and humidity level, which ensure the enhanced comfort for the occupants while optimizing the cooling demand and minimizing HVAC cost of the building. Further results of the energy simulation are indicated below.

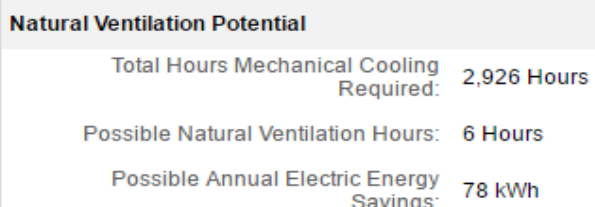

Figure 12. Natural ventilation potential

Wind Energy Potential

Annual Electric Generation: 306 kWh

Figure 13. Wind energy potential
Results of natural ventilation potential and wind energy potential shown in Figures 12 and 13 respectively, are important in deciding natural and artificial ventilation requirements inside the building to optimize the quality of indoor environment. The blend of natural and artificial ventilation is important to reduce the use of mechanical ventilation which leads to minimize the energy consumption of building.

Table 5. Solar PV simulation results

\begin{tabular}{ccccc}
\hline Month & $\begin{array}{c}\text { AC } \\
\text { Energy } \\
\mathbf{( k W h )}\end{array}$ & $\begin{array}{c}\text { Solar } \\
\text { Radiation } \\
\left(\mathbf{k W h} / \mathbf{m}^{2} / \mathbf{d a}\right. \\
\mathbf{y})\end{array}$ & $\begin{array}{c}\text { DC } \\
\text { Energy } \\
\mathbf{( k W h )}\end{array}$ & $\begin{array}{c}\text { Value } \\
(\mathbf{L K R})\end{array}$ \\
\hline January & 496.754 & 5.364 & 518.211 & $10,118.51$ \\
February & 531.845 & 6.559 & 554.049 & $10,833.33$ \\
March & 579.759 & 6.538 & 604.622 & $11,809.25$ \\
April & 471.824 & 5.505 & 492.413 & $9,611.111$ \\
May & 484.190 & 5.271 & 505.203 & $9,862.962$ \\
June & 409.032 & 4.471 & 427.263 & $8,331.481$ \\
July & 394.742 & 4.151 & 412.716 & $8,040.740$ \\
August & 453.340 & 4.839 & 473.448 & $9,235.185$ \\
September & 475.607 & 5.265 & 496.377 & $9,688.888$ \\
October & 500.313 & 5.499 & 522.237 & $10,190.74$ \\
November & 460.991 & 5.272 & 481.269 & $9,390.740$ \\
December & 456.300 & 4.973 & 476.867 & $9,294.444$ \\
Total & 5714.69 & 63.707 & 5964.675 & $116,407.40$ \\
\hline
\end{tabular}


Solar PV simulations were further conducted and analyzed resulted from the energy simulation as shown in Table 5. Monthly results of solar energy generation including Solar Radiation (kWh/m²/day), AC (Alternative Current) Energy (kWh), DC (Direct Current) Energy (kWh) and monthly costs of PV generation were obtained.

The resulted energy simulation outputs were important for the in depth understanding of energy consumption of the buildings avoiding the complications and difficulties of manual analysis. Several simulation results were compared with the actual results which have been manually calculated and thereby the validity of results was further confirmed.

\subsubsection{Step 05 - comparison with the actual results}

Simulation results were then compared with the available actual results of the building. The difference of the values was calculated as in Table 6 .

As presented in the table, there are slight differences between the simulated value and actual value. The reasons for the differences basically depend on the simulating method used in the software. It considers weather condition and data, geographical location of the building and building orientation in order to determine the impact of solar radiation to the building. Compared to the other values, the difference percentage of annual peak demand is high. However, this difference does not make an impact on the maximum demand charge and a change in maximum demand charge will only be inflicted for a difference percentage of above $+/-20 \%$.

However, this comparison was limited for several parameters as all simulation results given from Green BIM software cannot be manually calculated or taken. Due to the ability of Green BIM software to provide comprehensive energy simulation and performance results, Green BIM simulation results are more reliable and important for energy management of buildings. Comprehensive Green BIM simulations can be used to evaluate and analyze the energy performance of complex buildings. These energy simulation results are essentially important to get an in-depth idea of energy consumption and usage of the building and it provides the basis for decision making in optimizing the energy cost of the building. Through the understanding of building energy performances, organization can decide necessary strategies to reduce the energy consumption of the building. Organization could change the input data in accordance to the strategies decided and simulations results could be analyzed under each strategy, to decide the best option towards the desired objective. Since the BIM based building performance analyses are realistic and accurate, these results could be effectively used for building performance analyses.

Table 6. Comparison with actual results

\begin{tabular}{cccc}
\hline & Simulated Value & Actual Value & Difference \\
\hline Annual & Rs. 1,740,000.00 & Rs. \\
energy cost & $1,650,000.00$ & $-5.45 \%$ \\
& & $2,555,150$ & \\
Electric & $2,542,324 \mathrm{kWh}$ & $\begin{array}{c}\text { Kwh } \\
\text { (Annual } \\
\text { consumption) } \\
\text { Consumption }\end{array}$ & $0.5 \%$ \\
Fuel & $351,123.75$ \\
MJ/kg \\
Consumption
\end{tabular}

\subsection{Identified challenges during the use of Green BIM in the study}

While the significant energy simulation results were obtained from Green BIM software, there were various challenges faced during the study which should be identified by building owners and management prior to the application of Green BIM for the existing green buildings. Challenges were mainly classified as informational challenges, organizational challenges, functional challenges and technical challenges.

\subsubsection{Informational challenges}

Green BIM requires critical information where existing buildings sometimes have less compared to new constructions. In this study, energy related data were required to be input for the simulation software apart from the data identified from prevailing literature. Updating BIM information for the existing conditions of the building was also challengeable due to the uncertainty of the available data. Also, even the data available, as-built data were inefficient and inconsistencies and inaccuracies to the operational phase were observed during the use of Green BIM. 3D as built models were required to be highly accurate and therefore, accuracy of the data should be confirmed for simulations.

\subsubsection{Organizational challenges}

Organizational challenges were observed in managing the required information for the BIM model and simulations as there was a lack information transfer and management between the parties of the organization. Moreover, the issues in handling building documentation were also observed during the study.

\subsubsection{Functional challenges}

As functional challenges, difficulties in high modeling, creation of model objects, excessive time consumption and need of high efforts in creating and modifying existing BIM model were experienced during the study.

\subsubsection{Technical challenges}

As technical challenges interoperability and integration issues, incompatibility issues, unavoidable technical errors, were observed during the study.

Moreover, in this study, a guideline has been presented in Figure 14, based on the summary of research findings that could be supported for the future Green BIM practitioners and building owners for the use of Green BIM for existing green buildings.

\section{DISCUSSION}

Even the prevailing literature shows that the implementation of Green BIM for existing green buildings is less compared to the new buildings [36], this study revealed that existing green buildings can also be managed by Green BIM through the use of comprehensive building performance analysis. Moreover, the challenges that identified during the case study were further validated with the literature findings including inconsistencies and inaccuracies of existing data [44], incompatibility and interoperability issues of the Green BIM software [6], complicated efforts in creating as-built models and avoiding technical errors [43]. 
In this study, availability of the existing data was analyzed as it is significant in the implementation of Green BIM for existing buildings. Generally, when a building passed its design and construction phases, the data of design and construction phases are not available during the operational phase. This has caused the main issue for the lack of implementation of Green BIM during the existing phase due to unavailability of required data, because the data availability is the critical requirement for the use of BIM technologies into building projects.

Furthermore, to ensure the proper implementation of Green BIM techniques during the operational phase of existing green buildings, this study propose to conduct a rigorous preliminary survey to gather required accurate data in existing green buildings considering the Green BIM software used for the simulations. Integration and collaboration of stakeholders who have been involved during design stage of the building is also significant to eliminate the issues associated with as- built
Green BIM models. Conducting post occupancy evaluations, building performance analyses are also important prior to the implementation of Green BIM to ensure the consistency of data and information. Top management commitment, establishment of organizational policies and practices is further supportive and important to avoid the issues of document handling and integrity issues. As this study focused to assess the ability of using Green BIM, it can be concluded that, it is possible to generate Green BIM simulation results to enhance the energy performance of existing green buildings. The guideline proposed in the study, based on the research findings (Figure 14), will be beneficial for the Green BIM practitioners for the proper implementation of Green BIM for existing buildings.

To facilitate the research aim, this study focused on a single case study and come up with a conclusion that there is a potential to use Green BIM technology for the existing green buildings.

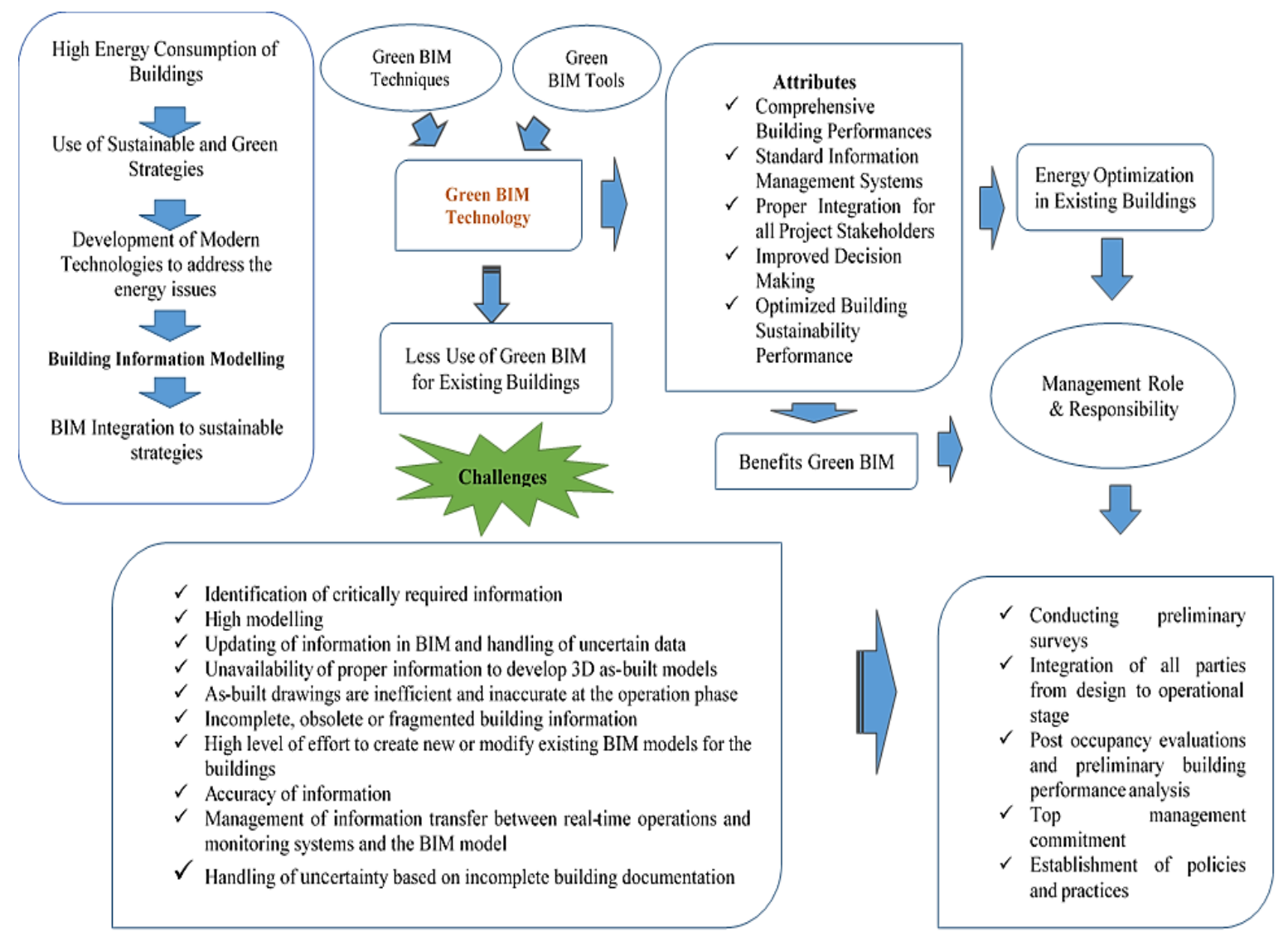

Figure 14. Guideline for the use of Green BIM

\section{CONCLUSIONS}

According to the aforementioned findings, though the data availability appears to be numerically satisfactory, there could be issues due to the lack of accuracy and reliability of data, which are hidden and invisible until practical implementation is initiated. Hence, even though the data are available apparently, a proper examination should be carried out in order to realize the accuracy and actual availability of data up to the accepted level. It is important to confirm the accuracy of data as much as possible to get the accurate simulation results from Green BIM software for existing buildings. However, this study conducted energy analysis using Green BIM, and it can be concluded that, there is a possibility of using Green BIM techniques for existing green buildings. Besides, further studies need to be undertaken to identify and evaluate this applicability when the level of data availability is different in green buildings.

\section{LIMITATIONS}

This study is limited to the single case study of an existing green building and only the energy simulation has been conducted. Moreover, the comparison of the simulated results with the actual results were limited as all the simulation results 
cannot be manually achieved. Thus, except the available actual results, other simulation results created from the software cannot be validated which is a limitation of this study.

\section{ACKNOWLEDGEMENT}

This work is supported by the Senate Research Committee, University of Moratuwa, Sri Lanka (Grant No.: SRC/LT/2017/20).

\section{REFERENCES}

[1] Ozturk, G.B. (2020). Interoperability in building information modeling for AECO/FM industry. Automation in Construction, 113: 103122. https://doi.org/10.1016/j.autcon.2020.103122

[2] Liao, L., Teo, E.A.L., Chang, R. (2019). Reducing critical hindrances to building information modeling implementation: The case of the Singapore construction industry. Applied Sciences (Switzerland), 9(18): 3833. https://doi.org/10.3390/app9183833

[3] Wong, K., Fan, Q. (2013). Building information modelling (BIM) for sustainable building design. Facilities, $\quad 31(3 / 4)$ : 138-157. https://doi.org/10.1108/02632771311299412

[4] Abanda, F.H., Tah, J.H.M., Cheung, F.K.T. (2017). BIM in off-site manufacturing for buildings. Journal of Building Engineering, 14: 89-102. https://doi.org/10.1016/j.jobe.2017.10.002

[5] Kymmell, W. (2008). Building Information Modeling: Planning and Managing Construction Projects with 4D CAD and Simulations. McGraw-Hill Construction Series.

[6] Motawa, I., Carter, K. (2013). Sustainable BIM-based evaluation of buildings. Procedia - Social and Behavioral Sciences, 74:

419-428.

https://doi.org/10.1016/j.sbspro.2013.03.015

[7] Solla, M., Ismail, L.H., Yunus, R. (2016). Investigation on the potential of integrating BIM into green building assessment tools. ARPN Journal of Engineering and Applied Sciences, 11(4): 2412-2418.

[8] Hui, S.C.M. (2019). New opportunities of using building information modelling (BIM) for green buildings. The 15th Asia Pacific Conference on the Built Environment: 5R Technology for Building Environment, 18-19 October 2019 (Fri-Sat), Kaohsiung, Taiwan.

[9] Ebrahim, A., Wayal, A.S. (2020). Green BIM for Sustainable Design of Buildings. Springer Singapore.

[10] Dall'O', G., Zichi, A., Torri, M. (2020). Green BIM and CIM: Sustainable planning using building information modelling. In Research for Development, 383-409. https://doi.org/10.1007/978-3-030-41072-8_17

[11] Ilhan, B., Yaman, H. (2016). Green building assessment tool (GBAT) for integrated BIM-based design decisions. Automation in Construction, 70: 26-37. https://doi.org/10.1016/j.autcon.2016.05.001

[12] Rathnasiri, P., Jayasena, S. (2019). Green building information modelling technology adoption for existing buildings in Sri Lanka. Facilities management perspective. Intelligent Buildings International. https://doi.org/10.1080/17508975.2019.1632782

[13] Lin, P.H., Chang, C.C., Lin, Y.H., Lin, W.L. (2019). Green BIM assessment applying for energy consumption and comfort in the traditional public market: A case study. Sustainability (Switzerland), 11(17): 4636. https://doi.org/10.3390/su11174636

[14] Khoshdelnezamiha, G., Liew, S.C., Bong, V.N.S., Ong, D.E.L. (2019). BIM-based approach for green buildings in Malaysia. IOP Conference Series: Earth and Environmental Science, 268(1): 012052. https://doi.org/10.1088/1755-1315/268/1/012052

[15] Maskil-Leitan, R., Reychav, I. (2018). A sustainable sociocultural combination of building information modeling with integrated project delivery in a social network perspective. Clean Technologies and Environmental Policy, 20(5): 1017-1032. https://doi.org/10.1007/s10098-018-1526-2

[16] Becker, R., Falk, V., Hoenen, S., Loges, S., Stumm, S., Blankenbach, J., Brell-Cokcan, S., Hildebrandt, L., Vallée, D. (2018). Bim - towards the entire lifecycle. International Journal of Sustainable Development and Planning, 13(1): 84-95. https://doi.org/10.2495/SDPV13-N1-84-95

[17] Mohammed, A.B. (2020). Collaboration and BIM model maturity to produce green buildings as an organizational strategy. HBRC Journal, 16(1): 243-268. https://doi.org/10.1080/16874048.2020.1807815

[18] Azhar, S., Khalfan, M., Maqsood, T. (2012). Building information modeling (BIM): Now and beyond. Australasian Journal of Construction Economics and Building, 12(4): 15-28. https://doi.org/10.5130/ajceb.v12i4.3032

[19] Wong, J.K.W., Zhou, J.X., Chan, A.P.C. (2018). Exploring the linkages between the adoption of BIM and design error reduction. International Journal of Sustainable Development and Planning, 13(1): 108-120. https://doi.org/10.2495/SDP-V13-N1-108-120

[20] El-Diraby, T., Krijnen, T., Papagelis, M. (2017). BIMbased collaborative design and socio-technical analytics of green buildings. Automation in Construction, 82: 5974. https://doi.org/10.1016/j.autcon.2017.06.004

[21] Wong, J.K.W., Zhou, J. (2015). Enhancing environmental sustainability over building life cycles through green BIM: A review. Automation in Construction, 57: 156-165. https://doi.org/10.1016/j.autcon.2015.06.003

[22] Edwards, R.E., Lou, E., Bataw, A., Kamaruzzaman, S.N., Johnson, C. (2019). Sustainability-led design: Feasibility of incorporating whole-life cycle energy assessment into BIM for refurbishment projects. Journal of Building Engineering, $24: 100697$. https://doi.org/10.1016/j.jobe.2019.01.027

[23] Ahuja, R., Sawhney, A., Arif, M. (2017). Driving lean and green project outcomes using BIM: A qualitative comparative analysis. International Journal of Sustainable Built Environment, 6(1): 69-80. https://doi.org/10.1016/j.ijsbe.2016.10.006

[24] Krygiel, E., Nies, B. (2008). Green BIM: Successful Sustainable Design with Building Information Modeling. Hoboken, NJ: Willey.

[25] Maltese, S., Tagliabue, L.C., Cecconi, F.R., Pasini, D., Manfren, M., Ciribini, A.L.C. (2017). Sustainability assessment through green BIM for environmental, social and economic efficiency. Procedia Engineering, 180: 520-530. https://doi.org/10.1016/j.proeng.2017.04.211

[26] Gan, V.J.L., Deng, M., Tse, K.T., Chan, C.M., Lo, I.M.C., Cheng, J.C.P. (2018). Holistic BIM framework for 
sustainable low carbon design of high-rise buildings. Journal of Cleaner Production, 195: 1091-1104. https://doi.org/10.1016/j.jclepro.2018.05.272

[27] Wu, W., Issa, R.R.A. (2014). BIM execution planning in green building projects: LEED as a use case. Journal of Management in Engineering, 31(1). https://doi.org/10.1061/(ASCE)ME.1943-5479.0000314

[28] Lu, Y., Wu, Z., Chang, R., Li, Y. (2017). Building Information Modeling (BIM) for green buildings: A critical review and future directions. Automation in Construction, 83: 134-148. https://doi.org/10.1016/j.autcon.2017.08.024

[29] Carvalho, J.P., Bragança, L., Mateus, R. (2019). Optimising building sustainability assessment using BIM. Automation in Construction, 102: 170-182. https://doi.org/10.1016/j.autcon.2019.02.021

[30] Shadram, F., Johansson, T.D., Lu, W., Schade, J., Olofsson, T. (2016). An integrated BIM-based framework for minimizing embodied energy during building design. Energy and Buildings, 128: 592-604. https://doi.org/10.1016/j.enbuild.2016.07.007

[31] Ahmad, T., Aibinu, A., Thaheem, M.J. (2017). BIMbased iterative tool for sustainable building design: A conceptual framework. Procedia Engineering, 180: 782792. https://doi.org/10.1016/j.proeng.2017.04.239

[32] Wong, J.K.W., Kuan, K.L. (2014). Implementing "BEAM Plus" for BIM-based sustainability analysis. Automation in Construction, 44: 163-175. https://doi.org/10.1016/j.autcon.2014.04.003

[33] Chong, H.Y., Lee, C.Y., Wang, X. (2017). A mixed review of the adoption of Building Information Modelling (BIM) for sustainability. Journal of Cleaner Production, 142: 4114-4126. https://doi.org/10.1016/j.jclepro.2016.09.222

[34] Biswas, T., Wang, T.H., Krishnamurti, R. (2013). From design to pre-certification using building information modeling. Journal of Green Building, 8(1): 151-176. https://doi.org/10.3992/jgb.8.1.151

[35] Barnes, S., Castro-Lacouture, D. (2009). BIM-enabled integrated optimization tool for leed decisions. Proceedings of the 2009 ASCE International Workshop on Computing in Civil Engineering, 346: 258-268. https://doi.org/10.1061/41052(346)26

[36] Azhar, S., Carlton, W.A., Olsen, D., Ahmad, I. (2011).
Building information modeling for sustainable design and LEED $₫$ rating analysis. Automation in Construction, 20(2): 217-224.

https://doi.org/10.1016/j.autcon.2010.09.019

[37] Gandhi, S., Jupp, J. (2014). BIM and Australian green star building certification. Computing in Civil and Building Engineering - Proceedings of the 2014 International Conference on Computing in Civil and Building Engineering, pp. 275-282. https://doi.org/10.1061/9780784413616.035

[38] Azhar, S., Brown, J. (2009). BIM for sustainability analyses. International Journal of Construction Education and Research, 5(4): 276-292. https://doi.org/10.1080/15578770903355657

[39] Raouf, A.M.I., Al-Ghamdi, S.G. (2019). Building information modelling and green buildings: Challenges and opportunities. Architectural Engineering and Design Management, 15(1): 1-28. https://doi.org/10.1080/17452007.2018.1502655

[40] Zanni, M.A., Soetanto, R., Ruikar, K. (2014). Defining the sustainable building design process: Methods for BIM execution planning in the UK. International Journal of Energy Sector Management, 8(4): 562-587. https://doi.org/10.1108/IJESM-04-2014-0005

[41] Bonenberg, W., Wei, X. (2015). Green BIM in sustainable infrastructure. Procedia Manufacturing, 3: 1654-1659. https://doi.org/10.1016/j.promfg.2015.07.483

[42] Wang, C., Cho, Y.K., Kim, C. (2015). Automatic BIM component extraction from point clouds of existing buildings for sustainability applications. Automation in Construction, 56: 1-13. https://doi.org/10.1016/j.autcon.2015.04.001

[43] Kim, H., Shen, Z., Kim, I., Kim, K., Stumpf, A., Yu, J. (2016). BIM IFC information mapping to building energy analysis (BEA) model with manually extended material information. Automation in Construction, 68: 183-193. https://doi.org/10.1016/j.autcon.2016.04.002

[44] Bu, S., Shen, G., Anumba, C.J., Wong, A.K.D., Liang, X. (2015). Literature review of green retrofit design for commercial buildings with BIM implication. Smart and Sustainable Built Environment, 4(2): 188-214. https://doi.org/10.1108/SASBE-08-2014-0043 